\title{
Drummond: primeira poesia
}

\author{
Alcides Villaça
}

Resumo O "Poema de sete faces", do livro Alguma poesia, encena algumas das oscilações dramáticas que constituem fundamentos da poética de Carlos Drummond de Andrade. Neste ensaio, busca-se determinar a natureza, as formas e os sentidos dessas oscilaçōes, tomando-se como ponto de partida a análise daquele poema, cujos traços de tensão se confirmam em outros textos do livro e compõem a base expressiva e ideológica da poesia inicial do poeta itabirano. Palavras-chave Carlos Drummond de Andrade, Alguma poesia, lírica moderna.

\footnotetext{
Abstract "Poema de Sete Faces", from the book Alguma Poesia, sets out some of the dramatic oscillations that constitute building blocks of Carlos Drummond de Andrade's poetics. The present paper intends to determine the nature, form and meanings of these oscillations, having as a starting point the poem's analysis. The taut outlines of the poem can be confirmed in other texts of the book, and set the expressive and ideological basis of the poet's initial work. Keywords Carlos Drummond de Andrade, Alguma Poesia, modern poetry.
} 
Na primeira poesia de Drummond - e de algum modo em todos os momentos essenciais de sua trajetória - o sentimento das experiências vividas ou projetadas manifesta-se como incompletude, às vezes declarada com todas as letras, em outras mascarada, sublimada ou ironizada. De início, há o grande álibi do fatalismo sentimental, que o poeta absorve como chancela de uma personalidade gauche, condenada à insuficiência no nascedouro, sob o signo do demonismo banal e desprestigiado de um desses muitos anjos tortos que "vivem na sombra" O poeta não teria como rebelar-se contra o desígnio do anjo sinistro, que vive na sombra e que reservou ao "malvindo" espaço igualmente lateral "na vida" Não nascerá daí, porém, uma poesia de lamentações: a fraqueza é apenas parte da verdade da condição original, sendo a outra o rigor que se determina como consciência poética. As impotências reverberam, assumidamente, no âmbito da expressão mais lúcida e iluminadora, constituindo-se assim o paradoxo dramático e nuclear da poética de Drummond. Toda experiência vital parece surgir como um desafio invencível para o sujeito, fadada a se cristalizar em objeto de sua contemplação abúlica; no entanto, o olhar desse tímido é também tão intenso em sua fome de inteireza que o próprio mundo das experiências acaba por se revelar "torto" nos seus descompassos, excessos, aberrações. Para muito além dos limites do eu e da vida imediata projeta-se, com força de ideal, o sentido de uma ordem ampla e verdadeira, que não se representa em lugar nenhum, mas que não deixa nunca de se oferecer como um horizonte. O ressentimento drummondiano origina-se da impossibilidade dessa ordem ideal, recortando-se contra um pano de fundo longínquo e afirmativo que, mesmo quando invisível, está suposto na perspectiva do discurso e é a contraface do modo irônico.

A precaução da consciência objetivante é adversária da idealização que anima o sujeito, tanto quanto as cautelas do realismo defensivo que o poeta armazena surgem como óbices para a epifania poética do mundo. Arma-se, assim, o curtocircuito essencial do discurso drummondiano, que se dá entre os pólos da condição individual e isolada do sujeito moderno, nos labores da difícil auto-identificação, e a instância mitopoética especulativamente trabalhada pela linguagem lírica. Face a face, esses espelhos supõem critérios incompatíveis de conhecimento e representação do mundo: o mito desdenha a razão pragmática, mas tão logo aludido esfuma-se no ar e oculta-se ao modo dos enigmas; a análise mais realista, por outro lado, constrange-se nos limites materiais da "vida besta", do ime- 
diatismo, da classe social de onde parece não ter como sair, mas na qual se constitui uma variadíssima plataforma de imagens e de valores em debate.

Da primeira fase modernista Drummond recolheu a possibilidade de humor e de confidência em tom prosaico, que o levou ao colóquio e a certa brejeirice de estilo - elementos ricamente combinados com o dramatismo de sua personalidade. No entanto, forçar até o fim a nota do piadismo oswaldiano (ao qual não resistiu algumas vezes) seria recurso artificial para um humor de base melancólica, assim como encampar os inquietos compromissos de Mário de Andrade com a cultura nacional teria para o gauche o sentido de uma sublimação indesejável, de um "seqüestro" inadmissível. Refratário aos conteúdos mais positivos da poética modernista (incluída a conquista de uma ordem pessoal, que Manuel Bandeira obtinha para sua outra e mais serena melancolia), Drummond valeuse, em todo caso, da pluralidade dessas inflexões recém-conquistadas pelo Modernismo de 22, fazendo delas uma espécie de arco estilístico cuja raiz obstinada é um sujeito de muitas faces, verdadeiro em todas e incompleto a cada uma. Tal pluralismo corresponde a forças em conflito dentro do indivíduo que, assim, se representa a si mesmo como núcleo de todos os paradoxos. O gauchismo não é apenas a face da insuficiência, mas a certeza altiva da impossibilidade de administração das contradições. Com o nome "Carlos" declarado em plena representação poética, a máscara retorna à biografia, à declaração de responsabilidade civil. No âmbito prosaico dessa certidão de batismo, o estilo modernista representa-se como anseio de constituição problemática da persona poética, sempre hesitante entre os mil apelos do mundo e os da própria consciência. Dramática desde a origem, essa hesitação acaba por cavar um profundo fosso entre o estilo pessoal e os programas modernistas, resultando numa apropriação ao mesmo tempo devedora e credora desses programas. A dívida se dá em relação às formas do novo lirismo que fulminou os ritos da convenção conservadora e que tantas perspectivas abriu para a apreensão e representação da vida; o crédito está no aprofundamento crítico e poético dessas perspectivas, de que surge uma consciência tensa e resistente às cláusulas programáticas, sofrendo a cada momento a necessidade de se determinar do modo mais rigoroso. Quando a ironia é tão verdadeira quanto a confissão seguinte, e quando esta logo se converte em humor para não afirmar em definitivo a gravidade do drama, o discurso poético adquire um padrão de instabilidade que gera ritmos, inflexões e imagens desnorteantes - revelações de beleza para nós outros, igualmente desconcertados.

$18 \neg$ Alcides Villaça 
Vista no conjunto, a poesia de Drummond é um longo e variado discurso que atravessou boa parte do século $\mathrm{xx}$ alimentando-se dos acontecimentos menores e maiores, pessoais e coletivos, somando-lhes o efeito íntimo da perplexidade e a tudo testemunhando de muitos modos. A força de testemunho de um poeta é, como se sabe, de natureza muito particular, nem sempre transparente. Na modernidade, as cifras da linguagem lírica parecem ser mais reveladoras que as confissões, dado que o desafio maior da arte moderna começa com a constituição mesma do sujeito criador. Libertado de convenções que lhe garantiam alguma forma de se ligar ou de se opor a tradições definidas, o escritor de nosso tempo é senhor e escravo da liberdade de perspectivas. Firmou-se com Baudelaire o reconhecimento a um tempo altivo e perplexo da pluralidade das formas e significaçōes da vida moderna. Na famosa alegoria de "L'albatros"', o poeta/pássaro tem que arrastar as asas pesadas e ridículas para divertir a tripulação entediada, encenando a liquidação do sublime, oferecendo-o aos retalhos aos marujos ou à multidão que passa nas ruas da metrópole. Ao desvelar a condição de gauche do moderno e pedestre poeta/albatroz, Baudelaire destronou o "prince des nuées", agora um "exilé sur le sol" - mas é bom lembrar que o poema ainda conserva a forma dos soberbos alexandrinos. Na poesia brasileira, esse sentimento da multidão urbana amadureceu com o modernismo paulista, que projetou a ainda provinciana paulicéia à condição de uma "ville tentaculaire" e trouxe para a discussão dos afrontados beletristas da época os temas da velocidade industrial, da cultura de massa, da história nacional, da psicanálise e das vanguardas estéticas. O desafio já não era o mesmo do albatroz baudelairiano: tratava-se agora de propor alguma resolução formal que despedisse de vez os sentimentos nostálgicos, o sublime tradicional e mesmo os acentos mais nítidos do grotesco romântico, para que uma nova linguagem viesse a encarnar os novos sentimentos e percepções do mundo que, se de um lado parecia ameaçador, de outro surgia de modo estimulante e envolvente.

A poesia de Drummond inaugura-se dividida entre a altivez de um sujeito decididamente fincado em seu próprio posto de observação e o sentimento de desamparo do tímido que bem desejaria sair dele para realizar sem culpa os "tantos desejos". Ao longo de décadas, sua poesia se desenvolve segundo os movimentos dramáticos dessa oscilação. Marcada por sucessivas alternativas e avaliaçōes, ele encontrará algum repouso nos livros da velhice, quando os olhos do poeta se vol-

1 Baudelaire, Charles. Oeuvres complètes. Paris: Robert Laffont, 1980, p. 7.

Drummond: primeira poesia $\ulcorner 19$ 
vem, de fora da "oficina irritada", para os quadros da infância e da juventude remotas (Boitempo I, II, III $)^{2}$, mas assinalará como seu definitivo epitáfio (Farewell $)^{3}$ a amargura da deficitária prestação de contas do "malvindo" diante dos ideais negados e das degradações do corpo, que anunciam a Morte imperturbável. Quem acompanhe essa poesia de modo diacrônico, no rastro das sucessivas tensões, traçará uma biografia íntima do poeta; quem reflita sobre a significação de seus passos e pondere as ligações mais agudas entre o sujeito e seu tempo problemáticos verá contada um pouco da nossa história.

Um poema O livro de estréia de Drummond - Alguma poesia (1930) - não é, como o título pode sugerir, uma coletânea meio descriteriosa, "arranjo" dos poemas díspares de um escritor iniciante; é, na verdade, o resultado de enxugamento de projeto anterior, uma "primeira arrumação"4, reavaliado seja na seleção dos poemas (muitos expurgos e alguns acréscimos), seja na refacção de boa parte deles. Ainda assim, o efeito imediato do conjunto pode trazer a sensação de disparidade, que o leitor experimentará na variabilidade dos estilos, das inflexões e das próprias personae do sujeito lírico: a linguagem se rege por padrões vários, as entonações abrem-se do pieguismo ao sarcasmo, e a identidade do poeta representa-se tanto na face mais humilhada quanto no olhar mais altivo. Parece justa, portanto, a fórmula com que Otto Maria Carpeaux definiu a heterogeneidade do conjunto: "notações sensíveis, descontínuas, características do impressionismo sentimental." $\mathrm{O}$ exame mais detido dos poemas pode neles valorizar, no entanto, o caráter dramático da "descontinuidade", o rigoroso jogo de posições do qual resulta não exatamente a variabilidade arbitrária, "sentimental", mas uma alternância dialética básica, promovida pela complexa consciência que o sujeito poético tem de si mesmo e do mundo. Ambos são instáveis na raiz, e a valorização de um ou de outro dependerá sempre do ângulo

2 ANDRADE, Carlos Drummond de.Obra completa. Rio de Janeiro: Aguilar, 1967.

3 Idem, Rio de Janeiro: Record, 1996.

4 DRUMMOND:"Primeira arrumação do meu livro Alguma poesia, que só seria editado em 1930" In: A lição do amigo. Cartas de Mário de Andrade. Rio de Janeiro: José Olympio, 1982, p. 87, nota 1. Ver também a carta "XIX (1.7.1926)",em que Mário se ocupa minuciosamente dos poemas dessa primeira versão.

5 Cf."Fragmento sobre Carlos Drummond de Andrade."In: Origens e fins. Rio de Janeiro: Casa do Estudante do Brasil, 1943, p. 333.

$20 \neg$ Alcides Villaça 
em que se instale a iniciativa: impacto da vida sobre o indivíduo, aqui defensivo e remordente, ou impacto da consciência sobre o mundo, ali onde a ironia parece se vingar da rotina e do senso comum. Digamos logo que o gauchismo funciona desde o início como confissão psicológica, dinâmica do estilo e lugar social (de onde se podem reconhecer a "vida besta" e o "mundo torto"). Vale dizer: a desqualificação do sujeito, por este mesmo promovida, funciona como índice de uma consciência mais alta e mais rigorosa, diante de cujo padrão tampouco o mundo está "direito", embora tenha este a iniciativa dos maiores impactos. Atribuído, pois, à oscilação mesma o peso de um critério fundamental, não resultará uma simples sucessão de formas hesitantes, mas a consciente exploração de um impasse fundamental: os valores do indivíduo e os do mundo são inajustáveis de saída, e a tarefa das imagens e dos conceitos poéticos estará em ao menos aclarar, no ritmo interno dos poemas ou na relação entre estes, os pólos que constituem uma precisa discordância. Não nos surpreenda, pois, o efeito paradoxal de proximidade afetiva e distância crítica que nos impõem esses poemas: o paradoxo é de fato normativo, valendo-se das alternâncias como fundamento daquele "jogo automático de alavancas de estabilização", na expressão feliz com que Manuel Bandeira surpreendeu na poesia inicial de Drummond esse mecanismo de compensações ${ }^{6}$.

A rigor, esses movimentos que aqui esboçamos não serão propriamente abandonados pelo poeta, até o fim de sua vida: sua poesia, essencialmente dialética, saberá manter-se como jogo de tensões básicas, variando na medida em que variem as predominâncias de um pólo sobre o outro. Falemos sempre em predomínio, com o cuidado de não absolutizar as "soluçōes" brandidas pelo poeta num poema, num livro, num momento de sua poesia, que implicam sempre uma mais velada e problemática contrapartida, essencial para a interpretação. Se o predomínio de uma fonte de tensões sobre outra alterna-se e permite-nos reconhecer movimentos estruturais dentro da dinâmica da obra - movimentos didaticamente reconhecíveis como fases - , isso não nos autoriza a formação de esquemas fixos, por natureza injustos para com a expressão dialética de que vive essa poesia. As tendências de um Drummond mais "anedótico", ou mais "social", ou mais "metafísico", são visíveis a olho nu, mas estão longe de explicar em separado a intimidade nervosa dos movimentos que as revelam. Não se entende, por

6 Cf. Poesia completa \& prosa. Rio de Janeiro: Nova Aguilar, 1985, p. 625.

Drummond: primeira poesia $\ulcorner 21$ 
exemplo, o poeta "participante" de A rosa do povo se se descuida do caráter dramático que assume essa participação enquanto desafio para a personalidade, para o lirismo, para a timidez do sujeito; também a "metafísica" poética de Claro enigma ficará encerrada no mais abstrato orfismo ou em vagas transcendências não venha a pontuá-la uma referência histórica da modernidade - referência quase sempre em negativo, sim, mas estruturante seja das soluções estilísticas, seja do particular desencanto em que mergulha o poeta.

A leitura seguinte, do "Poema de sete faces", busca adotar uma perspectiva para a compreensão desse amplo movimento que anima toda a poesia de Drummond. A interpretação desse importante poema e as notaçōes sobre vários outros do mesmo livro pretendem, pois, apreender o sentido dos primeiros passos, já dialéticos, de uma trajetória artística marcada por agudíssimo sentimento das contradições, as pessoais e as de seu tempo, marcadas numa particular dinâmica de formas poéticas.

Poema de sete faces

Quando nasci, um anjo torto

desses que vivem na sombra

disse: Vai, Carlos! ser gauche na vida.

As casas espiam os homens

que correm atrás de mulheres.

A tarde talvez fosse azul,

não houvesse tantos desejos.

O bonde passa cheio de pernas:

pernas brancas pretas amarelas.

Para que tanta perna, meu Deus, pergunta meu coração.

Porém meus olhos

não perguntam nada.

O homem atrás do bigode

é sério, simples e forte.

Quase não conversa. 
Tem poucos, raros amigos

o homem atrás dos óculos e do bigode.

Meu Deus, por que me abandonaste

se sabias que eu não era Deus

se sabias que eu era fraco.

Mundo mundo vasto mundo,

se eu me chamasse Raimundo

seria uma rima, não seria uma solução.

Mundo mundo vasto mundo,

mais vasto é meu coração.

Eu não devia te dizer

mas essa lua

mas esse conhaque

botam a gente comovido como o diabo.

Deixando de considerar as sugestões cabalísticas do número sete, fiquemos com a pluralidade simples e seu critério de composição. O termo "faces" conduznos a rostos e lados, feições e cortes lapidares - expressão humana e angulação geométrica. Enquanto partes, cada uma alude às outras e ao todo resultante delas; mas na particularidade de "faces" resgata-se o que também cada uma, a seu tempo e modo, quer expressar de forma completa. O movimento natural da leitura impõe uma seqüência: acidentada embora, uma história subsiste e é na verdade fundamental enquanto progressão articulada de uma confidência complexa. O que há de múltiplo à superfície está sob o permanente controle de uma consciência de fundo, que não deixa o aleatório ou o nonsense sobrepor-se à variedade dos afetos a que o sujeito está aberto ou, se quisermos, condenado. Sob a aparência de um jogo de caprichos e da mera descontinuidade, o leitor pode surpreender os movimentos de uma consciência dinâmica, cediça a todos os humores - mas cuja capacidade de auto-representação não deixa dúvida sobre quem está no comando. 
Quando nasci, um anjo torto

desses que vivem na sombra

disse: Vai, Carlos! ser gauche na vida. [grifo meu]

A figuração do tipo gauche $e^{7}$ tem em si mesma uma história, que se pode surpreender em ampla tradição literária e na própria biografia de Drummond. Uma filiação óbvia é baudelairiana, que por sua vez atualiza toda uma galeria de tipos desajustados ou malditos, a que no entanto não se deve dar expansão exagerada. Importe-nos mais o recorte deste gauche mineiro, formado em percurso já clássico de intelectual no Brasil: o caminhar em busca de um centro urbano econômica e culturalmente mais avançado, em que se superaria o primitivismo orgânico da província interiorana. Desta, podem conservar-se as raízes profundas da constelação familiar, a um tempo autoritária e protetora em seu círculo de ordem; daquele, ganha-se o ritmo de um novo cotidiano, na abertura para as captações da vida moderna, que se materializam num patamar mais alto de exigências culturais e num espelho muito mais problemático para a auto-identificação. A figura do itabirano em Belo Horizonte e, depois, do mineiro no Rio supõem a escala em que também se revelarão "um homem na América" e o "sentimento do mundo" - escala móvel na perspectiva drummondiana da desconfiança e da relativização. Entre as experiências fundantes da província, revividas e transfiguradas na memória, e as investigações intelectuais sobre o universal e o moderno, o sentimento nacionalista, por exemplo, pode surgir como uma mediaçāo artificiosa e imprópria, como a veleidade de se querer fixar um determinado caráter que o poeta não sabe e não aceita definir.

Por ocasião do "Poema de sete faces", o estreante Drummond está ainda num primeiro passo da perplexidade: o gauche se mostra sobretudo na insuficiência psicológica para a ação dentro de um mundo de movimentos rápidos e de excessivos convites. A primeira tarefa, para o poeta, é ter consciência disto, é iluminar a timidez na praça antes que seja acusada pelo outro - sempre um virtual demolidor. O sujeito não apenas ilumina sua timidez como a amplia e a categoriza com requinte, à francesa - "ser gauche" —, refinamento que subverte a confissão simplória e de quebra se contextualiza em quadro irônico, de aceno familiar.

7 Affonso Romano de Sant'Anna trata desta questão em Drummond: o gauche no tempo. Rio de Janeiro: Lia, INL, 1972.

$24 \neg$ Alcides Villaça 
A familiaridade está no pronome "desses", que traz para muito perto do nosso convívio "esses" anjos tortos de domínio público. Afastada assim a dimensão sobrenatural, inconveniente para o acenado registro autobiográfico, esse anjo-daguarda com sinal trocado aponta objetivamente para a fatalidade prosaica: "na vida" Nenhuma alusão ao sublime, ao principado das nuvens que Baudelaire contrapunha (como tema e como estilo) ao chão do cômico albatroz pedestre. A sombra e a tortuosidade estão na origem e no destino desse sujeito Carlos, que também assina o poema. $\mathrm{O}$ tom, mais para o ameno e o informativo, conjuga a circunstância do nascimento ao estigma em princípio trágico, temperando tudo na fluência oralizada de uma expressão inteiriça, que culmina na fala direta do anjo torto. O que o termo "sombra" pudesse colher de sinistro do reino de Lúcifer, remontando à origem da maldição divina, fica amortecido na frase coloquial e na banalização do ser maligno promovida pelo termo "desses" Caídos e multiplicados "na vida", anjos que vivem na sombra já não conferem a nenhum atormentado especial o infortúnio trágico de, por exemplo, um titã punido ou um herói sacrificado. A recusa à ênfase da excepcionalidade é a base do registro diminuído deste particular gauchismo. Toda a simbologia do nefasto, com seus tons sombrios e graves, resta desorientada com o coloquialismo da frase "Vai, Carlos, ser gauche na vida", que traz na camaradagem irônica um tempero de cinismo e irrisão. Na posição que ocupa na frase, o vocativo sustenta-se em entonação brejeira, oposta ao efeito de soluções mais graves e sentenciosas, como seriam, imaginemos, "Carlos, vai ser gauche na vida", ou "Vai ser gauche na vida, Carlos". De qualquer modo, há matizes na interpretaçāo dessa fala: é ordem enérgica, irrecorrível? É um deboche entre acanalhado e desafiador? Manifesta a superioridade irônica dos mestres de estoicismo? Traduz a melancolia cúmplice dos infelizes? Há argumentos para todos esses matizes, persistindo como fundo comum a idéia da desmitificação da queda como evento de grandeza trágica. Banalizado no prosaico da vida, o Diabo também está morto. A representação do Coxo se acomoda e se dilui entre tortos e gauches.

Mas o prosaísmo da lírica moderna não dispensa, de forma alguma, o acento expressivo dos signos. Nesta estrofe, ela se dá com a soma de "torto", "sombra" e "gauche", nomes que intensificam certo modo de ser "na vida" Bem examinados, os termos parecem sugerir desvios de uma ordem convencional, antítese desta, cujos correspondentes diretos seriam o iluminado, o direito, o retilíneoque trazem por analogia os predicados do equilíbrio, da racionalidade, da adap- 
tabilidade. Desmembrando-se mais possibilidades analógicas, todo um universo se constituiria com a reserva ético-político-moral de homens probos, de inegável retidão, centralizados com clareza numa sociedade bem comportada. É em relação a esse palco que se obscurece o do gauche, o dos tímidos e intimidados, dos inconvenientes, dos imobilizados. Reduzido este Carlos a um papel de mínima ou nenhuma atuação, cabe-lhe exercitar de seu canto a função de um embasbacado voyeur.

As casas espiam os homens

que correm atrás de mulheres.

A tarde talvez fosse azul,

não houvesse tantos desejos.

O olhar do sujeito transfere-se astutamente para o ponto de vista das casas, cuja personificação desloca o interesse de quem "espia" (olhar clandestino, desfrutante e protegido) a ciranda dos desejos expressos e decididos. De um ângulo de fora, o poeta espreita o primeiro motivo da "vida": a dinâmica erótica, o impulso que anima a correria dos homens que perseguem as mulheres que se fazem perseguir, numa "agitação feroz" (Manuel Bandeira), sim, mas com a mais precisa das finalidades. Dessa posição ao mesmo tempo cômoda e imobilizada, o tempo de "espia" opõe-se ao de "correm": fora da ação, o gesto se desdobra em solilóquio, análise, ponderação, afirmando-se na pura intimidade. $O$ voyeurismo se aproxima do de Baudelaire. A contribuição drummondiana à atividade do voyeur está na substituição da flânerie pela imobilidade e pela tocaia mineira, traços agudos da timidez. Também a cena de rua não surge em pleno verismo: o movimento espiado já é, de fato, uma abstração, traduzida como efeito de uma impressão elaborada e sintetizada pelo sujeito. A correria dos desejos, que num limite da imagem se prende atavicamente a um balé de faunos e ninfas no bosque mítico, é já o resultado cumulativo de sensações fundamente captadas. $\mathrm{O}$ ato de espiar e a cena espiada constituem uma metaforização do modo como se opõem a circunspecção paralisante do gauche e a dinâmica erótica dos homens e mulheres em pleno exercício "na vida"

Ao registro "descritivo" desses dois primeiros versos contrapõem os dois últimos uma espécie de notação íntima, que o termo "talvez" sublinha com seu tanto de dúvida e de especulação. Esse movimento psicológico tenta organizar, defensiva

$26 \neg$ Alcides Villaça 
e corretivamente, o mundo agitado lá fora: se não fosse assim ... talvez... Sentese, do lado de quem "espia", a imaginação compensatória do inadaptado, a formular idealmente uma "tarde azul" distante de tantos e tão aberrantes desejos. A dimensão idealizada - sempre uma referência na poesia de Drummond - surge aqui conotando a pacificação e profundidade da cor casada à tarde, sublimação em tom celeste dos desejos mundanos. "Tarde azul" roça algum chavão romântico, que o tímido "talvez" espreita com cautela, como a suspeitar da frouxa ingenuidade que se formula contra a ordem pragmática dos desejos. O gauche parece advertir-se da inocência lírica, atropelada pelos homens e mulheres que correm tão decididamente.

A modulação interna dessa estrofe é bastante didática: ilustra bem duas poéticas em tensão. Os dois primeiros versos lembram o Oswald dos instantâneos em tom infantil, que consagram o interesse pelas coisas oferecidas em bruto à observação aparentemente desarmada; pendem para um estilo de sínteses antimetafóricas, comprometido com o approach da cena prosaica que fingem retratar tal e qual, mas que na verdade transfiguram a um golpe quase imperceptível de humor e poesia (arte em que, aliás, o mestre maior é Manuel Bandeira, em textos como o "Poema tirado de uma notícia de jornal"). Já os dois versos restantes correspondem a uma hesitação bem drummondiana, àquela falta de confiança no afirmar ou no negar categoricamente - hesitação que nunca chega a eliminar do horizonte o espectro dos valores absolutos. Traduzem esses versos o lado especulativo e inquieto, a necessidade de projetar símbolos e de edificá-los numa retórica internamente corroída pelo rigor da autocrítica. $\mathrm{Na}$ soma, esses dois momentos da estrofe traçam a dialética entre a afetividade idealizante e a consideração do real, movimento em que a melhor poesia de Drummond se mantém. Algo de circunstante afunila-se em síntese do imediato; algo de permanente está sempre aberto à especulação. Entre a sombra de onde se espia e a luz azul da tarde há uma porosidade que a divisão das “faces" do poema não elimina, antes intensifica, como se pode ver com a leitura da estrofe seguinte:

O bonde passa cheio de pernas:

pernas brancas pretas amarelas.

Para que tanta perna, meu Deus, pergunta meu coração.

Porém meus olhos

não perguntam nada.

Drummond: primeira poesia -27 
A terceira estrofe acentua e determina elementos da segunda. Aqui estão de novo o $e u$, o olhar e os desejos, numa outra constelação, a que também não faltam o movimento e os excessos. Desapareceram os homens, e as mulheres (melhor dizendo: suas pernas) condensam-se no bonde que passa rápido diante do voyeur. O verso "pernas brancas pretas amarelas" é metonímico e cinematográfico: a velocidade do bonde modernista exige a atenção do espectador no corte interessado da câmera detalhista - corte evidentemente erótico, a aproximar o gauche do movimento da rua, a traduzir sua imobilidade em pasmo e anseio semiconfessados. O caráter excessivo das ofertas do mundo se confirma: aos "tantos" desejos do momento anterior somam-se agora "cheio" (de pernas) e "tanta" (perna). Vai-se constituindo, cada vez mais materialmente, a impressão de um mundo plural, intenso, aliciante - e inapanhável, para o olhar do tímido. Essa específica relação eu/mundo é, como se sabe, estrutural na obra do poeta: representa-se numa inconformidade trabalhada de muitos modos, nenhum deles esquemático ou falto de tensão. Aqui, a tensão se dá entre a pergunta mimeticamente saltitante do coração ("Para que tanta perna, meu Deus": leia-se com aproveitamento expressivo do ritmo e dos sons oclusivos da seqüência $/ \mathrm{p} / / \mathrm{k} / \mathrm{t} / / \mathrm{t} / / \mathrm{p} / / \mathrm{d} /$ ) e a significativa concentração dos olhos "que não perguntam nada". "Meu Deus" avizinha-se de uma pura interjeição, mas se somado à alusão a Cristo e ao imaginário satânico não deixará de integrar uma atmosfera cristā, em que se debatem a culpabilidade e as sublimações latentes (ser fraco, vasto coração, tarde azul). As razões do coração angustiado convivem mal com o interesse imediato dos olhos: dividido entre o pasmo remordente e a imposição dos desejos, o sujeito é patético, e fixa seu estilo nesse tom. Por sua vez, o leitor receberá com impacto uma confissão grave formulada com algum ridículo - modo astuto pelo qual o poeta "ingênuo" administra sua ingenuidade. A inconveniência deste gauche está em que ele constrói com seus próprios tropeços uma modalidade de poesia dramática, impregnada desse humour característico. $O$ diabo, como também um anjo torto, é o espírito inteligente capaz do riso mais cruel.

O homem atrás do bigode

é sério, simples e forte.

Quase nāo conversa.

Tem poucos, raros amigos

o homem atrás dos óculos e do bigode.

$28 \neg$ Alcides Villaça 
A quarta estrofe se singulariza bastante entre as sete: talvez seja a "face" mais intrigante. Isto virá do uso exclusivo da terceira pessoa gramatical, por meio da qual se retrata "o homem" O desnorteio está em que se abandonou, aparentemente, a instância lírica, consumando-se o passo na descrição objetiva de um rosto e de uma personalidade. O único elemento perturbador dessa ordem é o termo "atrás", que pode remeter à idéia de máscara e de encobrimento. "O homem" surge em ótica exteriorizante, e a perspectiva confidencial do sujeito parece esgotada, dando lugar aos traços frios de uma identificação com foto $3 \times 4$ e sumária descrição de comportamento. Tal "caracterização de personagem", digamos assim, dá conta de sua sisudez, de sua discrição e fortaleza moral, bem como da virtude de escolher a dedo os amigos. Parece nada ter a ver com o Carlos gauche da primeira estrofe, com o voyeur pasmo da segunda, com o atormentado espectador de pernas da terceira. Mas em nenhuma dessas estrofes o sentido de um deslocamento se fez tão intenso: é pelo espelho do olhar alheio que o sujeito se mostra agora, e a contradição não poderia ser maior: "atrás dos óculos e do bigode" - isto é, ainda na superfície exposta do rosto - não há gauchismo algum; a caricatura compõe-se de traços de respeitabilidade e cerimônia, reforçada pelo laconismo formal e pela seleta roda de amigos. A figura corresponde à do jovem Drummond da década de vinte, tal como se pode ver nas fotos da época e no retrato literário que lhe fez o amigo Pedro Nava. Este abonou "os óculos de sempre", "a boca bem desenhada meio encoberta pelos bigodes da época", a "expressão geralmente séria". Nava depôs ainda: "Era muito reservado, quase verecondioso - o que não quer dizer que deixasse de ser conversado."

A invasão do auto-retrato retoma, ainda que veladamente, a linha meio autobiográfica da primeira estrofe, mas recusa-se agora a combinar-se com os acentos íntimos da sombra e do gauchismo. Para o plano mais exteriorizado do olhar (oposto ao do "coração"), a figura é de força e não deixa transitar nada além do que os óculos e o bigode já desenharam como a imagem chapada do "homem" Repare-se, ainda, na construção desta estrofe: o primeiro verso está todo no último, alongado e mantido enquanto retorno rítmico e semântico. A figura do círculo, assim sugerida, é poderoso símbolo da imutabilidade, da unidade original, do equilíbrio; traduz o perfeito fechamento da linha que não se prolonga para além do movimento já traçado; supōe o centro (Plotino: o centro é o pai do cír-

8 Cf. Beira-mar: Memórias/4. 2ª ed. Rio de Janeiro: José Olympio, 1979, p. 171-5. 
culo), e com ele o ponto de eqüidistância e equilíbrio. O modo de composição acompanha e protege a figura retratada, fixando-a numa íntegra geometria. Nada mais contrastante em relação à obliqüidade do olhar gauche, aos excessos do mundo que ele observa, ao deslocamento do anjo torto. Qualquer lembrança de gauchismo vai aqui para muito atrás da figura, que nos dá a imagem do tipo contrário: há uma força de cerimoniosa civilidade nesse "homem" sisudo, que atua convincentemente com a máscara da polidez e da secura, em tudo refratário aos excessos; ele é definido, aliás, pelo restritivo e pelo negativo ("quase não conversa", "poucos, raros amigos"), opondo-se assim aos "tantos" e aos "cheios" de momentos anteriores. A seqüência desnorteia: em vez da intimidade atônita, a figura de rigoroso equilíbrio; em vez do voyeur dividido, a planura da persona circunspecta. A face mais visível é a mais intrigante: o que de fato se oculta para muito mais "atrás dos óculos e do bigode"?

A estrofe seguinte pode ter uma resposta:

Meu Deus, por que me abandonaste

se sabias que eu não era Deus

se sabias que eu era fraco.

Do momento mais seco saltamos para o mais confidencial. Se a estrofe anterior mostrava a inteireza da figura e da personalidade, indicadas num ele descritivo e prosaico, esta fala encarna agora a fragilidade absoluta, acentuando liricamente a sensação mais profunda: "me abandonaste", "eu não era Deus", "eu era fraco". Promovido o diálogo entre este "fraco" e aquele homem "forte" dos óculos e do bigode, ressurge o sujeito dividido - agora mais dramático na intensa polarização das duas faces contraditórias: administração consciente da imagem pública em diálogo imediato com a confissão aberta de um cósmico abandono. Auto-suficiência plena, num nível; insuficiência absoluta, em outro. Se a imagem do "homem sério" associa-se facilmente a um padrão de prestígio exterior e à correspondente estabilidade social, a condição de "abandonado" confina-o no plano do vazio íntimo. Para uma, concorreu o estilo impessoal de uma ficha lacônica; para outra, convocou-se a própria linguagem do Evangelho e a agonia de Cristo na cruz. Entre a seca objetividade e a Paixão revivida à margem do sublime, trava-se a relação desidentificadora que está na base da poesia de Drummond: a verdade última dos afetos não tem expressão possível, e toda tentativa de maior alcance esbarrará na produção canhes-

30 - Alcides Villaça 
tra de um símbolo precário (um elefante desengonçado, uma flor feia, uma rosa comercial, um arabesco perdulário). A verdade íntima é a da carência, aqui expressa numa retomada profana da fala de Cristo que Mateus e Marcos (mas nāo Lucas e João) consignaram: “Deus meu, Deus meu, por que me abandonastes?" A invocação drummondiana, matizando-se em tom de prece nos sussurros sibilantes da aná-

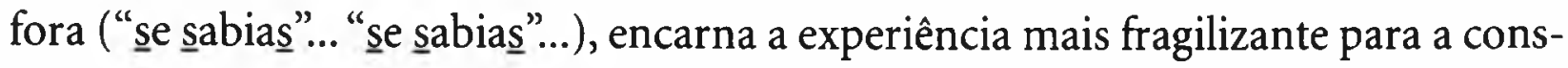
ciência humana, no silêncio eterno em que a solidão se cristaliza e em que os braços pendem inertes. Terá Cristo encontrado na dúvida e no sentimento de abandono a experiência da mais forte comunhão com a fragilidade das criaturas?" Ao homem moderno, aqui representado, faltaria, em todo caso, a ponte com o divino ("se sabias que eu não era Deus"), e a sua objetiva fraqueza ecoa num mundo material já sem traço de sublime - "na vida". O poema foi composto no Natal de 1928, mas a comoção lírica evoca a religação impossível: despido da máscara e da ironia, o gauche é carência plena entre os excessos mundanos. Entende-se por que a "tarde azul" e as perguntas do coração surgiam tão deslocadas: são elementos intrusos e indefensáveis, como que vestígios terminais de uma vontade lírica sem expressão na ordem pragmática, à qual responde melhor a modelar composição de óculos, bigode e secura, que circula na quarta estrofe. Não é difícil sentir-se aqui o quanto o sujeito assume (para dolorosamente abandoná-lo em seguida, como se verá) o tom proibido das confissões diretas. A presença ativa da consciência - consciência também da linguagem, do estilo, da tradição da lírica — não permite a manutenção da fragilidade: exercita-a no contexto moderno da dessublimização, minando-a no contraste com um outro inacessível Saber: "se sabias", "se sabias". O gauchismo ganha aqui a nota trágica — mas igualmente efêmera, na sucessão sem repouso das tantas "faces" Também o Verbo, convocado num misto de contrição e ceticismo, apenas de passagem iluminou uma verdade nascida para não durar.

Mundo mundo vasto mundo

se eu me chamasse Raimundo

seria uma rima, não seria uma soluçāo.

Mundo mundo vasto mundo,

mais vasto é meu coração.

9 A última frase de Cristo, nos evangelhos citados, é o primeiro versículo do "Salmo 22" e suscita muita interpretação.

Drummond: primeira poesia $\ulcorner 31$ 
No primeiro verso, a linguagem conserva ainda o ritmo e a gravidade do momento anterior: "Mundo mundo vasto mundo" está impregnado de solenidade, aparentemente ampliando o sentimento do abandono com o topos do "mundo grande". A impressão é mesmo de ascese do momento confessional e intimista da quinta estrofe para alguma instância elegíaca de largo fôlego, aqui anunciada pelo tom - mas o leitor terá é que descer, com a linguagem, à piada de um Raimundo que rima e não é solução. Com esse intruso, tão motivado quanto arbitrário pela mesma razão da rima, vemo-nos reconduzidos ao chão das palavras e ao seu jogo de caprichos, que o ritmo gauche do terceiro verso ajuda a realizar. A ineficácia da rima e da medida setissilábica é potenciada com escândalo pelo ritmo desencontrado do verso bárbaro "seria uma rima, não seria uma solução". $O$ conjunto capenga dessas catorze sílabas obstrui implacavelmente a prometida seqüência de redondilhas dos versos anteriores, que, é bem verdade, já começava a desafinar na estridência do prosaico "Raimundo" No plano do estilo, é a concretização mesma do fenômeno de uma queda: uma tradição lírica, musicalmente acolhida, esbarra na ordem estranha de uma sentença prosaica. O motivo da imensidão íntima se esborracha contra a superfície constrangedora dos dicionários de rima e o chão pragmático da busca de soluções.

É de se esperar que o leitor acompanhe o poeta nesse novo passo, reafinando o ouvido para - quem sabe? - captar alguma livre seqüência de nonsenses, piadas e dissonâncias; mas, no novo diapasão, ele encontrará de volta duas redondilhas maiores: uma, o reiterado "Mundo mundo vasto mundo" (com suas assonâncias graves e anasaladas), e outra, o verso ambiciosíssimo "mais vasto é meu coração", em que a rima pobre e sem efeito de paródia recupera aquela "solução", abandonada no terceiro verso. Antológica com justiça, esta face/estrofe põe no pạlco dois critérios de grandeza incompatíveis: o sempre excessivamente grande mundo da vida, no qual um tímido desafina e se apequena, e o absolutamente vasto universo interior, em que o mundo não pesará mais do que a mão de uma criança. Radicalizados, o lírico e o prosaico fazem supor o critério de uma harmonia igualmente superior, acima do plano facetado da condição moderna. Num espelho de contrários, o mundo torto e o sujeito gauche dimensionam-se ambos por uma virtude que não se estabiliza nem em um nem em outro - ao mesmo tempo em que se excluem mutuamente. São faces contíguas e autônomas, ligadas mas descontínuas, movimentando-se segundo a lei de uma alternância dramática. O estilo drummondiano encarna essa alternância valendo-se tanto do valor emocional da con- 
fissão lírica quanto do parâmetro realista em que aquela se faz gauche. A blague é uma verdade mundana na mesma medida em que o sentimento é uma verdade íntima; combinar ironia e despojamento - o ajuste crítico da pilhéria às razões do coração - é toda a empreitada absurda a que se lançam os sísifos da arte moderna, numa dialética sem repouso. A rápida alternância da força e da fraqueza manifesta-se no jogo poético do discurso drummondiano, onde rimas sāo e não são solução, onde o tradicional e o novo tecem a recíproca inviabilidade, onde o gauchismo e a lucidez se corroem reciprocamente. Em suma: esta sexta face encena, na velocidade de seu movimento interno, o jogo das inflexōes alternadas, traduzido em estilo que nasce ora da apreciação objetiva do mundo, ora da sensação de uma verdade absoluta que dispense objetivaçāo.

Eu não devia te dizer

mas essa lua

mas esse conhaque

botam a gente comovido como o diabo.

Estrofe de recolhimento e síntese, a sétima e última atua poderosamente sobre as demais, dando voz a uma espécie de avaliação final das alternâncias e das contradições. Tocada de perto pelo categórico "mais vasto é meu coração", em que o sujeito se abeirava do pleno romantismo, ela se abre com um cauteloso "Eu não devia te dizer", em que a virtual confissão tanto parece envergonhar o confessor quanto diminuir o confidente. Mas ambos estarão a salvo pela marota introdução de um tertius (o par "essa lua"/"esse conhaque"), a que se imputa a responsabilidade por quaisquer excessos. $\mathrm{O} e u$ e o $t u$ reinstalam-se, pois, naquela mesma cumplicidade diante do anjo torto, "desses" que vivem na sombra, tão familiares, afinal, quanto "essa" lua e "esse" conhaque, que "botam a gente comovido como o diabo". A recomposição da familiaridade é gaiata como quem pisca um olho, dissolvendo assim o que reste de trágico da fraqueza do abandonado, ou o que sobre da gravidade formal do "homem atrás do bigode". Aderindo à prosa da vida e à solução modernista meio oswaldiana, o sujeito transmuda as aflições cósmicas em confissão de mesa de bar, mineiramente ponderando o risco de ter sido inconveniente. Lida desta forma, a estrofe é mesmo um epílogo, e a comoção geral se encerra com a esperta justificativa. Entendida, porém, com um caráter de maior independência, ela pode agir num sentido oposto, anun- 
ciando, por força agora da lua e do conhaque, desdobramentos virtuais da comoção presente. Como o poema de fato termina aqui, o silêncio abriga tanto a brusca suspensão dos excessos confessionais quanto o eco perturbador das queixas e ironias já constituídas. O jogo é o de sempre: trata-se de afirmar não só a iniludível verdade das comoções como também a da circunstância determinante da lua e do conhaque que as provocou. Uma vez mais, a inflexão contrita de um primeiro momento ("Eu não devia te dizer") desemboca na inflexão catártica e banalizante de um momento posterior ("botam a gente comovido como o diabo"). Na ordem modernista, os eflúvios do conhaque e a nostalgia do luar não se sobreporão à comunicabilidade que o poeta deve assumir "na vida", próximo de um leitor igualmente sem aura e potencialmente "comovido como o diabo". A alusāo satânica também está fora de qualquer órbita romântica, conformada à prosa gasta em que já se reduziu a uma quase interjeição ("como o diabo!"). Não obstante, tudo o que essa estrofe disfarça, toda essa sua dissimulação é que acaba por intensificar a verdade das comoções de todo o poema: conhece-se esse humor irônico que, ao simular desfazer a melancolia, ainda mais a acentua. Acolhendo os antagonismos do nosso tempo, no qual o afeto e a razão podem cristalizar-se como se fossem vocações contrárias, o discurso poético de Drummond arma as faces incongruentes e nos faz reconhecer o espelho partido.

Reconhecidas as faces em seu movimento dramático de falas e inflexões (e não numa imobilidade de colagem), qualifica-se também o tempo lírico que dá ritmo à unidade possível do poema. Resta investigar essa qualidade na ação que já transcende o plano morfológico, reconhecendo-lhe a repercussão de sentido num plano cultural mais amplo.

Uma questão rudimentar, mas também decisiva, coloca-se sempre diante de um poema intimista: como foi mesmo que ganhou o nosso interesse? A resposta não se completa com a justificativa do gosto, também este, aliás, uma intrigante questão cultural; a resposta depende da sondagem de confluências em geral pouco visíveis, mas sem dúvida estruturais, entre a fala do poeta e a receptividade emotiva e intelectual do público nele implicado. Sem subestimar a pluralidade dessas confluências e a diversa natureza delas, não desistamos de buscar reconhecê-las. Sabe-se que a poesia lírica projeta contra qualquer outra ordem de discurso sua voz muito particular, expressão de uma verdade íntima que podemos reconhe- 
cer com surpresa. Nessa surpresa do reconhecimento reside o efeito de paradoxo do poema lírico, menos paradoxal, porém, se admitimos a correspondência da intimidade nossa com uma verdade mais geral, no interior de uma "corrente subterrânea coletiva"10. Que reconhecimento específico permite-nos compartilhar com interesse da expressão sedutora do "Poema de sete faces"?

Partindo da evidência: no clima dele reina uma instabilidade psicológica que impede a fixação da perspectiva única, descaracterizando-se exatamente o sentido mais tradicional de lirismo, sentimento que emerge do individuum, isto é, do ser indivisível, uno, irredutível. Multiplicando-o em distintas faces a partir de um simulacro de autobiografia, Drummond dota o seu sujeito da identidade complexa de quem está sempre fora de alguma ordem de expectativa, valendo-se para isso de uma expressão que tampouco repousará na uniformidade de estilo. Até aqui a pluralidade não espanta, pois confina com a atitude modernista que tem a fragmentação como critério. O ganho está em ultrapassar a atitude pragmática e encarnar com peso realista a necessidade escancarada das personae, movimentadas pela instabilidade essencial do sujeito: um amálgama de confissões e ironias. Numa encruzilhada histórico-estética em que múltiplos e contraditórios valores parecem disponíveis, a falta do rosto pessoal é preenchida por uma sucessão de esboços seus, desierarquizando-se planos e temas, sensações e sentimentos, conceitos e imagens. A potencialidade do verso livre modernista, com tudo o que ele implica, é acionada em seu dispositivo fulminante: aquele que faz explodir, no interior da linguagem, a ilusão de um ponto de vista unificador. Abre-se ao sujeito a traiçoeira possibilidade das multiplicações — "liberdade" a que cada poeta não deixa de estar condenado.

Tal liberdade Drummond a exercita com o "grão de angústia" de seu humor crítico; integra-a, aqui, numa biografia possível, a que não faltam premonições dos grandes temas de sua poesia. O leitor mais íntimo de sua obra reconhecerá neste poema, correndo sob e entre os versos, uma história de motivos bem familiares: a maldição original (como a lançada pelos ancestrais no extraordinário "Os bens e o sangue"), a inquietude das paixões amorosas (como em "Tarde de maio" ou "Campo de flores"), a perda da ordem provinciana (como em "Confidência do itabirano"), o contraponto entre o ritmo da intimidade e o da cidade grande (co- 
mo em "A bruxa"), os dilemas da classe média e do poeta funcionário público (como em "A flor e a náusea"), a culpa íntima e irresgatável (como em "A mão suja"), a ilusão da decantada conciliação brasileira (como em "Hino Nacional"). Conciliação: sobretudo esta parece imiscuir-se entre as oscilações e tentar afinar em definitivo o tom geral do "Poema de sete faces" Como que buscando salvar o desalinho do conjunto das seis estrofes anteriores, na sétima o poeta puxa o leitor pelo braço e deixa subentendida alguma camaradagem de base, um nível de confidência em que todas as contradições se explicariam como um simples e familiar descalibramento sentimental. $\mathrm{O}$ verso "botam a gente comovido como o diabo" (talvez intraduzível, enquanto expressão e sentimento de um difuso falar mineiro-brasileiro) redimensiona toda a complexidade estética do poema e os diferentes planos existenciais do sujeito, trazendo tudo para o contexto de prosa amiga e complacente, espécie de cadinho ideológico de uma sociedade cujas antinomias buscam resgatar-se em já proverbiais "no fim dá certo", "é conversando que a gente se entende", "o diabo não é tão feio quanto se pinta" etc. Aquilo que de vivo e de verdadeiramente tumultuado se representou no poema multifacetado tende à supressão final de todas as exaltações, oferecendo-se o poeta à compreensão prosaica de seu hipócrita (mas no fundo um bom camarada) irmão leitor. Como que refeitos ambos da aventura complexa da personalidade e das dilacerações modernas, podem agora reencontrar-se numa espécie de saída mineira para as angústias universais: a explicação do patético, do ridículo e do grave como conjunção meramente circunstancial de fatores sentimentais, de que a vida está cheia e de que ninguém está isento. Pode-se reconhecer nesse passo um acréscimo drummondiano à caracterização geral do gauchismo: ver-se como diferença do outro, ser a diferença para o outro, apresentar-se como diferença até em relação a si mesmo - mas sempre encontrar uma fórmula de sobrevivência naqueles sentimentos que, precária e consoladoramente, acabam por identificar "a gente" Drummond faz desse contraponto crítico-sentimental uma expressão dinâmica dos limites que são também os de seu público, modulando na voz as sensações secretas e estruturando-as em consciência no diálogo das contradições.

Outros poemas Se não me escapou o sentido básico da pluralidade que se expressa no "Poema de sete faces", bem como certo efeito de síntese poética e existencial que o marca em definitivo, as "faces" podem ainda conduzir-nos na tarefa

$36 \neg$ Alcides Villaça 
de assinalar as várias perspectivas que dão a Alguma poesia sua feição compósita. A pluralidade é também do livro, e o desafio está em identificá-la (enquanto variedade das formas apresentadas) e em interpretá-la (divisando-se o critério da instabilidade geral).

Não há por que não aceitar, a princípio, as razões do gauchismo em que o sujeito se instala - desde que o termo resulte bem determinado, como síntese das contradições que tecem a dinâmica nervosa da subjetividade e do estilo, de um lado, e o penoso imobilismo prático em que o sujeito rumina suas perplexidades e sua ironia, de outro. Esse paradoxo central, que a melhor poesia de Drummond tantas vezes encenará, foi desde cedo reconhecida por Mário de Andrade como o encontro (e o desencontro) da alta inteligência com a profunda timidez do poeta - "coisas que se contrariam com ferocidade" ${ }^{\prime \prime 1}$ Se bem entendemos a análise psicológica feita por Mário, a contradição estaria entre o impulso para ação, a que análise e inteligência das situações instigam, e as barreiras emocionais, que a personalidade do tímido ergue à sua volta. Dessa mesma instância contraditória nasceria o sentimento de culpa, acompanhado por uma irônica sublimação em que a consciência negativa adquire altivez: "mais vasto é meu coração". Reduzindo-se e ampliando-se alternativamente o eu e o mundo, jamais solidários num mesmo plano, dramatiza-se o impasse de um desencontro, cujos pólos mais visíveis são o gauche e o "vasto mundo", numa das relações, e o sujeito auto-suficiente e a "vida besta", em outra. As sucessivas trocas de posição têm, como é óbvio, conseqüências drásticas nos diferentes planos da visão de mundo, da poética, do estilo, da psicologia lírica e da assimilação da História. Tal como se dá exemplarmente no "Poema de sete faces", em Alguma poesia o leitor está obrigado a dançar segundo o tom, o ritmo e o andamento desencontrados dos vários momentos: aqui, o epigrama ferino; ali, a fala confessional; acolá, uma anedota bem "modernista"; mais adiante, um manifesto de alta voltagem ideológica — sem falar da memória sentimental e da narrativa satírica. Tamanha descentralização faz pensar em caprichoso arbítrio exercido pelo jovem poeta, subitamente armado com o potente arsenal modernista. "Livre que nem uma besta" (como em "Política"), o moço escritor estaria se exercitando irresponsavelmente nos vários códigos e jogos de posição abertos pela recente vanguarda? O exercício de fato parece existir, mas não como simples capricho. $\mathrm{O}$ percorrer atento de alguns poemas

11 Cf."A poesia em 1930". In: Aspectos da Literatura Brasileira. 6a ed. São Paulo: Martins, 1978, p. 33. 
mais significativos permite o reconhecimento dos lugares ocupados pelo sujeito e, por trás de tudo, as determinações íntimas e insistentes, que fazem compreender a natureza complexa de tantas "inquietudes"12.

Uma antinomia básica (aqui como em outros livros) nasce da difícil composição entre $\mathrm{o}$ apego $\mathrm{e} o$ desapego pelas origens familiares, confundidas com o estatuto da família patriarcal e o universo provinciano, entre a identificação e a desidentificação com a recém-aberta perspectiva modernista, a que o poeta adere com relativização e desconfiança. Esses pares antinômicos geram um ângulo muito pessoal para a elaboração poética: favorece o modernismo no que este tem de experimental e libertário, mas também coloca entre parênteses críticos suas cores mais eufóricas e o que haja de ingênuo e totalizante na afirmação dos projetos. Provam-no as restrições que tem Drummond ao antropofagismo de Oswald, bem como sua falta de adesão ao nacionalismo do amigo Mário (que não deixou de lhe recriminar o absenteísmo e as excessivas precauções da inteligência diante da emoção). A respeito da questão do nacionalismo, note-se que a antinomia, em Drummond, não se dá exatamente entre o "nacional" e o "universal", mas sim entre o regional e o mundo, recusando-se o poeta mineiro ao que parece considerar, no nacional, uma indesejável mediação entre a vivência concreta $\mathrm{da}$ pessoa e a humaine condition. $\mathrm{O}$ atrito de fato parece resultar mais polarizado, passando por cima da problemática "identidade nacional" e desenhando logo o impasse de um itabirano enfrentando o "mundo" - desproporção de que o poeta sabe extrair seu álibi, com os efeitos mais graves ou mais irônicos. Melhor se desenvolvem estas afirmações anotando-se um poema, exemplar para o caso, que é "Cidadezinha qualquer"

\section{Cidadezinha qualquer}

Casas entre bananeiras mulheres entre laranjeiras

pomar amor cantar

Um homem vai devagar.

12 Categoria com que trabalha Antonio Candido em "Inquietudes na poesia de Drummond". In: Vários escritos. São Paulo: Duas Cidades, 1970.

$38 \neg$ Alcides Villaça 
Um cachorro vai devagar.

Um burro vai devagar.

Devagar... as janelas olham.

Eta vida besta, meu Deus.

A primeira estrofe é uma estampa singela, a que não faltam as linhas de um desenho de caderno infantil, desenho tosco e meio chapado, a representar pelas imagens e pelo tom um cenário familiarmente idílico. $O$ idílio se acentua no terceiro verso, uma construção muito feliz, em que os nomes "pomar" e "amor" surgem contaminados pela ação do infinitivo "cantar", as três formas coabitando uma mesma suspensão temporal que sugere eternidade. A leitura em voz alta dessa estrofe deve ser imitativamente muito lenta, para bem realizar o andamento da vagarosa colagem executada por um sujeito contemplativo e absorto.

$\mathrm{Na}$ estância seguinte, explicita-se esse ritmo interiorano, em que os movimentos do "homem", do "cachorro" e do "burro", fraternalmente nivelados, se fazem cada um por sua vez "devagar" O advérbio labora, com sua raiz verbal (vagar), para imprimir à ação de ir um aspecto de errância entre solene e vagabunda. No entanto, o efeito de idílio desaparece: a tríplice ocorrência de "devagar" é exasperante e encaminha ao tédio, sem prejuízo de alguma comicidade nervosa que parece estar por trás de um estilo sem recursos. A descrição repetitiva fornece um quadro agora incômodo da cidadezinha modorrenta; o ponto final em cada verso isola sem esperança o fotograma da monotonia; a simetria e a indigência sintática dos três versos acentuam a irritante conformação do estilo. O sétimo verso, destacado, dá conta de uma inversão: a qualidade mesma de "devagar" é surpreendida agora no tipo de contemplação que provém das janelas, onde ancoram olhares igualmente eternos, transfundindo do quadro provinciano (e ao mesmo tempo incrementando nele) a sensação de estaticidade dominante. As reticências levam a um clímax (!) o andamento lentíssimo dos vagares e dos olhares.

É quando surge, abrupto, o verso final: fala que tenderia ao grito, não sugerisse a pontuação discreta o devido recolhimento da observação exasperada. É fala indiscutivelmente interiorana, num coloquialismo aberto, quase uma autocaricatura; e no entanto seu ponto de vista escapa com velocidade da paralisia geral, acionando impiedosa crítica na qual desponta um sujeito bastante desloca- 
do. O verso torna definitivamente irrecuperáveis o idílio inicial e o tédio seguinte, dando lugar ao inconformismo e à condenação implacável do ritmo local. O poema encerra-se, portanto, com a eleição de um lugar outro, insuficientemente determinado, mas sugerido como alternativa crucial para uma perspectiva crítica em que o sujeito recua da paisagem provinciana e insinua $o$ seu outro lugar. Que lugar é esse?

A resposta nos leva para além de algum ponto propriamente estabilizado; levanos para o movimento crítico do sujeito, o eixo rotativo que já vimos agir na alternância das "sete faces", o sucessivo deslocamento do olhar sentimental para o irônico, do lirismo confessional para o diminuidíssimo "épico" das pequenas cenas ou micronarrativas. Um pólo supõe o outro, como sugere o movimento pendular, e o deslocamento vai-se oferecendo a si mesmo como um critério permanente, variando nos extremos as formas com que se apresentam os objetos da antinomia. No caso de "Cidadezinha qualquer", o movimento se faz exemplar: a imobilidade inicial do quadro idílico, meio casimiriano, pode ser traduzida como estabilidade prazerosa; os lentos gestos flagrados na segunda estrofe firmamse como repetição incômoda e abusiva; e os versos finais trazem a ruptura e outra (aparente) fixação do sujeito, agora em órbita distinta, de onde solta a imprecação ruminada que vira desabafo em sentido quase corporal. Registra-se aqui uma espécie de fórmula de emancipação pessoal, expressa por estilo que já traduz o sentimento de diferença de quem se desprendeu de um universo arcaico e estático para aplicar sobre ele o olhar da crítica e do humor modernos.

Lido o poema avulsamente, poderíamos especular quanto a um gesto de renúncia definitiva do poeta que exorciza o provincianismo de origem, instalando-se, também em definitivo, no lugar que lhe cabe na modernidade. Esta, de fato concretizada nos manifestos modernistas dos escritores de São Paulo, fez-se presença física de alguns deles, na forma de caravana bandeirante pelo solo belorizontino $^{13}$. Reclamava-se dos jovens postulantes locais atitude igualmente combativa e compromissos que não elidiam questões como a do "caráter nacional", da "fala

Drummond:"Em abril de 1924, hospedou-se no Grande Hotel de Belo Horizonte um grupo de excursionistas (não se falava ainda em turismo interno) procedentes de São Paulo, que fora a Minas Gerais em visita às cidades históricas, ao ensejo da Semana Santa. Era composta por Dona Olivia Guedes Penteado, seu genro Godofredo Teles, a pintora Tarsila do Amaral, o poeta francês Blaise Cendrars, os escritores Mário de Andrade e Oswald de Andrade (...)." "Apresentaçāo" a A lição do amigo, op. cit., p.vII.

$40 \neg$ Alcides Villaça 
brasileira". das "nossas raízes" etc. Atitude e compromisso que não deixam de estar presentes, como plataforma grupal (mas com redação de Drummond) na apresentação ("Aos scepticos") de A Revista ${ }^{14}$. Ocorre que entre a ideologia ali explicitada e a prática poética do jovem itabirano está um verdadeiro abismo: a apresentação editorial é sisuda, de espírito missionário, crivada de constrangedores lugares-comuns, enquanto nos poemas do mesmo período Drummond traça movimentos incomparavelmente mais complexos.

Consulte-se, ainda, o desconcertante "Explicacão" - poema que Mário de Andrade, antes de conhecer o "de sete faces", recomendara a Drummond como pórtico do livro ${ }^{15}$ :

\section{Explicação}

Meu verso é minha consolação.

Meu verso é minha cachaça. Todo mundo tem sua cachaça.

Para beber, copo de cristal, canequinha de folha-de-flandres,

folha de taioba, pouco importa, tudo serve.

Para louvar a Deus como para aliviar o peito,

queixar o desprezo da morena, cantar a vida e trabalhos

é que faço meu verso. E meu verso me agrada.

Meu verso me agrada sempre...

Ele às vezes tem o ar sem-vergonha de quem vai dar uma cambalhota, mas não é para o público, é para mim mesmo essa cambalhota.

Eu bem me entendo.

Não sou alegre. Sou até muito triste.

A culpa é da sombra das bananeiras de meu país, esta sombra mole, preguiçosa.

Há dias em que ando na rua de olhos baixos

para que ninguém desconfie, ninguém perceba

que passei a noite inteira chorando.

Estou no cinema vendo fita de Hoot Gibson,

de repente ouço a voz de uma viola...

saio desanimado.

14 Cf. número I, julho de 1925. Belo Horizonte:Tipografia do Diário de Minas, p. 11.

15 Cf. A liçāo do amigo. Op. cit., p. 86.

Drummond: primeira poesia $r 41$ 
Ah, ser filho de fazendeiro!

À beira do São Francisco, do Paraíba ou de qualquer córrego vagabundo, é sempre a mesma sen-si-bi-li-da-de.

E a gente viajando na pátria sente saudades da pátria.

Aquela casa de nove andares comerciais

é muito interessante.

A casa colonial da fazenda também era...

No elevador penso na roça,

na roça penso no elevador.

Quem me fez assim foi minha gente e minha terra

e eu gosto bem de ter nascido com essa tara.

Para mim, de todas as burrices a maior é suspirar pela Europa.

A Europa é uma cidade muito velha onde só fazem caso de dinheiro

e tem umas atrizes de pernas adjetivas que passam a perna na gente.

$O$ francês, o italiano, o judeu falam uma língua de farrapos.

Aqui ao menos a gente sabe que tudo é uma canalha só,

lê seu jornal, mete a língua no governo,

queixa-se da vida (a vida está tão cara)

e no fim dá certo.

Se meu verso não deu certo, foi seu ouvido que entortou.

Eu não disse ao senhor que não sou senão poeta?

Longo e prosaico, fazendo também no espírito jus ao título, o poema tem fôlego e liberdade para desenvolver, a par das imagens, conceitos e posiçōes muito reveladores. Acentuarei nele apenas os lances que considero decisivos nessa específca "explicação"

As duas primeiras frases anunciam o método geral, que é o de definir tudo por meio de um insistente movimento de contradiçōes. "Meu verso" é "minha consolação" e "minha cachaça": arte consoladora, em regime de contrição e lirismo, e obsessão viciosa como a da pinga, na verificação mais prosaica, em que aliás o poeta pode se identificar com "todo mundo" (expressão de valor análogo ao de "a gente", do "Poema de sete faces"). Definido (ou, também, indefinido) o largo espectro da compulsão poética, com a mesma largueza definem-se os seus meios de expressão, seus continentes formais: "copo de cristal", "canequinha de folha- 
de-flandres", "folha de taioba" - formas ligadas ao requinte, ou à simplicidade doméstica, ou à rusticidade primitiva, "pouco importa: tudo serve" Seguindo com o poema, Deus, a dor-de-cotovelo e a vida em geral ilustram esse "tudo serve" no plano libérrimo dos temas, assim como o "ar sem-vergonha", "a cambalhota" galhofeira e a tristeza profunda ilustram a heterogênea composição sentimental, debitada à "sombra das bananeiras de meu país, esta sombra mole e preguiçosa" $\mathrm{O}$ débito pode ser lido como sátira e caricatura dos componentes de um caráter nacional identificável como indolente, inzoneiro, melancólico, cordial, sentimental, em suma: legítimo produto das "três raças tristes". Já a modernidade entra pelo cinema norte-americano e por Hoot Gibson, ameaçando uma saída positiva... que no entanto acaba no "desanimado" filho de fazendeiro, sensível ao som de todas as violas...

Mais explicitamente pendular é o movimento que se desenha a seguir, até o fim do poema. O verso "E a gente viajando na pátria sente saudades da pátria" tem a notável ambigüidade de quem parece enaltecer o valor indiscutível do torrão natal, mas não o vê concretizado em lugar algum. A fórmula é ao mesmo tempo cívica e agônica, pois "a gente" habita um país que se dá como ausência, lembrando uma desidentificação bastante comum, vazada em construções do tipo "brasileiro é assim mesmo", em que as culpas se deslocam para a terceira pessoa. A "culpa" parece ser de fato do invisível país, da abstração em que também se dissolvem o "governo" ou "os políticos", encerrando-se nesse âmbito providencial uma "explicação" fatalista para todos os males. Em todo caso, esta índole analítica das supostas "raízes" ficou mais complicada, pois à "roça" opõe-se o "elevador", à "casa colonial" opõe-se o edifício de "nove andares comerciais", tudo sugerindo uma ordem nova e inquietante. Como para fugir a uma inédita e mais difícil "explicação", o poeta busca agarrar-se à primitiva, não sem acentuar o que há de cômico em seus argumentos: reafirma que "quem me fez assim foi minha gente e minha terra" (ao mesmo tempo em que se mostra orgulhoso da "tara" nativa); desqualifica a Europa, fingindo confundi-la com alguma vaga e distante cidade onde se falam outras línguas, velhas e exóticas; e volta a enaltecer o "aqui" e "a gente", na forma tão nossa de autodefinição: "é tudo uma canalha só" Tudo leva ao direito de concluir pelo axioma nacional do "no fim dá certo" - misto de malandragem e de escatologia cristã.

A argumentação é brilhante, desconcertante, sem fugir um milímetro de uma espécie de filosofia do senso comum do brasileiro pouco instruído, ou então da- 
queles instruídos que a sabem apresentar como boa ideologia. O efeito geral desses versos lembra o de alguns irônicos textos machadianos, em que fica difícil se divertir até o fim com a jocosidade de base grave e realista. A síntese da argumentação de Drummond brinca com a complicada questão da auto-estima feroz e do autodesprezo que permeiam não sei se exatamente classes, talvez camadas conservadoras da população brasileira (há algo de típico, por exemplo, no indigente bêbado que reage a provocações num bar sacando do bolso algum documento em farrapos e gritando: "olha aqui, ó, eu sou brasileiro!"). No poema, "a gente" se define, em todo caso, como leitores de jornal e críticos sistemáticos do "governo", o que sugere cidadãos de opinião formada que se queixam da mesma vida que "no fim dá certo"

Parasse o poema por aqui, o poeta restaria um tanto mergulhado no risível senso comum, e mesmo a ironia poderia soar com relatividade. Mas o fecho vem em dois versos que complicam a leitura mais cômoda:

Se meu verso não deu certo, foi seu ouvido que entortou.

Eu não disse ao senhor que não sou senão poeta?

A "complicação" da "explicação" se dá sob a forma de um divórcio estético, que lança suspeitas sobre as cumplicidades, sobre a consensualidade que vinha servindo ao poeta e ao leitor. A possibilidade de o poema no fim "não dar certo" já é tratada como um fato, cujo prejuízo se desloca e se debita do lado do leitor: um outro para esse $e u$ que não é "senão poeta" Imputando a esse outro lado a tortuosidade que costumava ver em si mesmo, o sujeito poético mina as certezas conservadoras do "verso certo" (sendo difícil esquecermos o que havia de canônico, de belles lettres e de oficialismo na poesia dominante da época), afirma uma espécie de nova afinação para a poesia e, dentro do restritivo - "não sou senão poeta" - garante-se um espaço de liberdade imprevista. Vê-se logo que a discrepância estética é mais do que isso: trata-se de um movimento novo, certamente modernista, mas também muito pessoal, em que os versos já não se restringem à pura "consolação", mas adotam a crítica e o humor que deixam muito deslocada a idelogia do senso comum e que, sem exaltar o lugar do poeta, tornam ridículas as expectativas do leitor convencional. A operação lembra muito a de Baudelaire e seu "hypocrite lecteur", atualizada e particularizada nas condições peculiares deste mineiro e de seu público.

$44 \neg$ Alcides Villaça 
O paroxismo que salta dessas sistemáticas trocas de valor, em que o poeta se mostra em perfis ora afirmados, ora negados, fica sobretudo visível quando comparamos poemas. Em "Poesia", por exemplo, a arte poética é pura virtualidade, o verso "não quer sair", enquanto "a poesia deste momento / inunda a minha vida inteira", o que lembra a atitude romântica, a infinita subjetividade, a latência como essencial etc. - sem prejuízo da expressão em tom corriqueiro que alude a essa impossibilidade como, no fundo, inessencial: a "minha vida" sobrepõe-se altivamente a qualquer circunstância. Já em "Sweet home", a vida, que é "um bruto romance", reduz-se sarcasticamente ao "gozo de minha poltrona", ao "chá de minha burguesia contente", ao "bocejo de felicidade", deslocando-se o seu sentido para a sombra das proclamações mais realistas. Diante do tormento da divisão ou do paraíso da auto-suficiência, a individualidade de Drummond vê ambas as pontas com radicalismo, mas não se fixa em nenhuma, optando pelo trânsito nervoso da consciência mais aguda ao lirismo mais desarmado e vice-versa trânsito que retira de ambos os lados a inteireza da "solução" - como vimos no "Poema de sete faces"

Outro par sugestivo pode ser armado com "Infância" e "Sesta" No primeiro, a memória recupera os esteios da meninice dentro da família: o pai proprietário e cavaleiro, a mãe costurando, a preta velha na cozinha, o irmão pequeno dormindo - quadro em que tudo se estabiliza e do qual se solta a imaginação do poeta-menino, leitor de Defoe identificado com o Robinson solitário que sabe organizar seu próprio mundo. A ordem familiar é protetora, não lhe faltando mesmo algum traço épico (o pai/Ulisses campeando no "mato sem fim da fazenda" enquanto a mãe/Penélope cose e aguarda) e um contorno intimista (o ninar da preta velha, o olhar da mãe). A poesia surge aqui como extensão natural daquele mundo. Os versos fluem sem qualquer ironia, as imagens se fixam fora de qualquer contradição, ressalvando-se, quando muito, apenas o tom melancólico em que o poeta, no presente do adulto, lamenta o "não sabia" - o que aliás vem reforçar a plenitude da cena evocada. O mundo antigo, rústico e organizado a seu modo, era mais bonito.

Muito diversa é outra família, retratada no poema "Sesta". Aqui, uma "família mineira", simples e modorrenta, engasta-se num mundo também rústico e ordenado, mas a que faltam o traço épico e qualquer possibilidade lírica - elementos que se integravam à memória poética de "Infância". A letargia em "Sesta" é total, e obsta qualquer iniciativa das personagens. Os gestos e as palavras, míni- 
mos, sugerem o abandono dos corpos e da própria imaginação. A fatura do poema fica entre o cômico e a crueldade do observador: versos como "A família mineira / está comendo banana" adotam uma gravidade incompatível com a ruminação dada como prosaica e vegetativa dos degustantes. Detalhes muito miúdos ("A filha mais velha / coça uma pereba / bem acima do joelho") tornam-se risíveis em elocução sentenciosa. Sobretudo sugestivos são os olhares das personagens e seus respectivos alcances: o registro "O filho mais moço / olha para o céu" pode ameaçar um devaneio e um desprendimento poético, mas o poeta logo acode: "para o sol, não, / para o cacho de bananas", mostrando que ali todo interesse é estritamente prosaico. A linha do horizonte é, de fato, "a cerca da horta”, onde o mundo parece que se detém para sempre, mundo que não deve ter sua gozosa modorra ameaçada sequer pela inquietação de um "mosquito rápido" e atrevido, logo enxotado por "importuno" De fato, "A família mineira / olha para dentro", sacramentando-se aqui um matutar prazeroso e auto-suficiente, "calado e feliz" - quadro que combina harmoniosamente com aquele traçado em " $\mathrm{Ci}$ dadezinha qualquer", e que cristaliza, no livro, um lugar primitivo, ancestral, termo perfeito para entrar em dialética com a "música mecânica dos linotipos", com o automóvel, com o espantoso engenho dos "paletós [que] abotoam-se por eletricidade"16.

O leitor não se cansará de encontrar em Alguma poesia pares dessa antinomia geral, que Drummond interioriza como viva contradição e que expressa na incongruência dos tons e dos estilos. Em "O que fizeram do Natal”, há a tradição do velho presépio, em que as beatas adoram "o deus nuzinho", e há os "clubes sem presépio", em que as filhas das beatas vão namorar e dançar o black-bottom; em "A rua diferente", os mais velhos "não se conformam" com o progresso que desfigura a rua, mas a menina se diverte com a "luz da solda autógena"; em "Itabira", a notícia aparentemente banal ("Os ingleses compram a mina") repercute como tragédia em Tutu Caramujo que - temperamento formado na sugestiva casca do apelido - "cisma na derrota incomparável", "na porta da venda" cujos dias estão contados; em "Belo Horizonte", os "jardins versailles" e "as árvores tão repetidas" do moderno planejamento urbano convivem com o elemento singelo da "casinha de alpendre com duas janelas dolorosas"; em "Sabará", a cidadezinha

16 John Gledson considera a "divisão do poeta entre duas alternativas incompativeis" em Poesia e poética de Carlos Drummond de Andrade. São Paulo: Duas Cidades, 1981, p. 69.

$46 \neg$ Alcides Villaça 
histórica está "calada, entrevada", "atrás daquele morro, com vergonha do trem"; já em "Rio de Janeiro", a cidade surge como um feixe de "fios nervos riscas faíscas", futurismo contrastando com o coração do poeta que, dentro do táxi, "vai molemente"; o Papai Noel moderno de "Papai Noel às avessas" entra na casa furtivamente, torce o comutador, faz a eletricidade bater nas "coisas resignadas" $\mathrm{e}$ — sinal dos tempos! - sai também furtivamente, com a trouxa cheia de brinquedos recolhidos no quarto dos meninos abastados.

Enfim: se há de um lado a indiscutível afirmação de uma nova poética, moderna e potencialmente incorporadora de todos os ritmos, há, de outro lado, a sensação de desgaste e de tédio que surge para o sujeito prematuramente desencantado, e que já se declara "o sobrevivente", depois de afirmar que "O último trovador morreu em 1914" e que "Há máquinas terrivelmente complicadas para as necessidades mais simples". O deslocamento tanto enseja quanto ameaça comprometer o lugar mesmo da formação poética; a nova lírica nasce simultaneamente ao prosaísmo que a nega, não dando tempo para os manifestos e os compromissos de natureza afirmativa. Alguma poesia tem poemas que remontam a 1924, e boa parte do livro estava pronta muito antes de 1930; considere-se, portanto, que sua perspectiva pouco otimista, ainda que às vezes ligeira, armou-se contemporaneamente a algumas das plataformas de Oswald, Mário, Menotti, Cassiano, Raul Bopp e outros que, por vias e ideologias tão diversas em sentido e em importância, encaminhavam com garra "leituras" crítico-construtivas do passado nacional e incisivos diagnósticos sócio-culturais.

Talvez a mais forte contribuição de Drummond para o conjunto de idéias e programas do período tenha sido, exatamente, declarar-se inapto para empolgá-las, criando com isto um ângulo de observação muito independente e original, em princípio não-participativo - "descompromisso" que no entanto o deixava livre para o exercício de um lirismo novo, muito pessoal, e essencialmente crítico. O alegado canhestrismo de gauche torna-se modo privilegiado de estilo: já não haverá surpresa nos contínuos deslocamentos de quem proclamou a inadaptação como critério, e timbra seu discurso com um individualismo exacerbado, oferecido como um anti-modelo. $O$ pacto com o leitor só ocorre na medida em que este também aceite o desconforto da pluralidade, a simulação ingênua e a inteligência aparentemente inútil e imobilizante: pois toda a movimentação interna dos poemas, bem como a que nasce da relação entre eles, parece desembocar na inarredável "pedra no meio do caminho", símbolo fecundo deste livro e dos impasses em geral. 
Veja-se, pois, que as "sete faces" multiplicam posições mas não perdem a coerência da sistemática instabilidade. Sustenta-se, no fundo de tudo, a individualidade poética, mas não com a nitidez fisionômica de íntegra personalidade lírica, muito menos com as garantias convencionais do sujeito poético indiscutido e tipificado (sonhador romântico, artesão parnasiano, místico simbolista). A individualidade nasce como problema, prefigurando o que será a tradição de um lirismo mais desconcertado, aberto a planos de difícil coesão, como o intimista-político, o confessional-irônico, o místico-hedonista, o cético-formalista etc.

Um plano problemático da poesia de Drummond expressa-se como sentimento (des)orientado pela multiplicidade dos fatos, como vocação individualista que busca uma perspectiva social, como timidez que se desmascara na origem para mais convincentemente se desidentificar nos tantos atropelos da vida. A arma irônica é apenas meia-verdade do sujeito drummondiano, estando a outra no difuso idealismo que combate a primeira. Pelo viés de uma ironia absoluta, o eu gauche e o mundo errado consagrariam a harmonia negativa, no fundo uma harmonia sistematizável em sarcasmo; pela perspectiva de um puro idealismo, o eu e o mundo se encontrariam ao menos enquanto projetos afirmativos, deixando que toda negatividade repousasse como contingência do presente. Vimos, porém, que o dramático do movimento está na contínua disparidade entre os planos, na impossibilidade da afirmação simultânea do eu e do mundo, ou mesmo da negação definitiva de ambos. No entanto, se há perdas para a integridade psicológica e para a objetivação do real, há um notável ganho crítico e poético na manutenção dessa dialética, em que tanto a agonia do sujeito quanto a tortuosidade do mundo podem iluminar-se mutuamente, na dinâmica entre lirismo e sociedade cujo teor mais fecundo foi tão bem interpretado por Adorno.

A leitura de Alguma poesia não deixará de notar que esse movimento que vimos insistentemente repisando não se ausenta mesmo dos poemas aparentemente menos "dinâmicos": a piada de "Anedota búlgara", mais que um sestro do modernismo, oferece como questão a barbárie relativizada como mero ponto de vista; em "Música", a péssima execução de Chopin ouvida ao piano encontra nas dificuldades prosaicas do poeta ("contas que era preciso pagar") um substrato mais forte para a nostalgia romântica e a liberação dos cuidados reais, que "voaram como borboletas" por causa desse Chopin enquadrado em particular tristeza: o poeta provê com preocupações efetivas da vida a melancolia que surgia tão vaga na execução pseudo-artística. De fato, o movimento parece revelar-se não en-

$48 \neg$ Alcides Villaça 
quanto ação, propriamente dita, do sujeito, mas como reanimação dos fatos a cada sinal instável da perspectiva lírica.

A variedade da vida, que o poeta acolhe tão impressivamente, impõe-se ao sujeito como desafio para a inteireza da personalidade. Abolindo desde logo a ilusão de totalidade, com aquela declaração de gauchismo, o indivíduo desafiado deixase atingir pelos fatos, que comparecem como num calidoscópio temático: desejo amoroso, memória familiar, reflexão cívica, ruminação da ideologia do progresso, crônica do cotidiano, história do Brasil, reportagem política, breviário estético, expiação moral etc. Acompanhando a pluralidade, as linguagens refundem vozes de poetas modernistas, que podem ecoar à Manuel Bandeira (em "Lagoa"), à Oswald de Andrade ( em "Política literária"), à Mário de Andrade ("Cantiga de viúvo", "Explicação"); e há espaços simbólicos em que se problematizam as operações mesmas do fenômeno da representação: a "lanterna mágica" do turista, o cinema que é capaz de historiar o "amor através das idades", a imaginaçāo vingativamente exótica que se faz do estrangeiro ("Europa, França e Bahia"), a execução do ritual religioso ("Romaria"), a coreografia sensual ("Cabaré mineiro"). A vitória dos fatos, dos "tantos desejos" sobre o sujeito inapto parece incontestável, e teria como saldo a afirmação final e triunfante da matéria múltipla, indomável do cotidiano, o caráter fatalmente avulso dessa "alguma" poesia que sobrou das circunstâncias. Ocorre, no entanto, que a aparente passividade do sujeito é tão deliberadamente exposta, e o é com tamanho requinte e precisão, que a "derrota" existencial do tímido só existe no quadro preciso dessa mesma exposição, vale dizer, num padrão de desempenho estético dos mais altos da literatura em língua portuguesa. Nesse sentido, o gauchismo se revela uma estratégia apta ao exercício de todos os paradoxos: a persona estética e estilística só ganha em coerência, com os sucessivos deslocamentos, tornando a descontinuidade de que se investe uma condição excelente para reproduzir o pluralismo dos fatos. Em outras palavras: nascendo como alegada deficiência existencial e psicológica, a perspectiva gauche descompromete-se de qualquer projeto consistente, sem porém deixar de exercer, à sombra da ironia, a liberdade de projetar-se em todas as faces do real. É essa malícia que está, por exemplo, no centro do poema "Esperteza": o tímido que se lança ao esporte de amar uma loura torna-se, de início, "brinquedo nas suas mãos", e "apanharia"; mas, "acabado o jogo", "ela ficaria espantada I de ver um homem esperto" Que reviravolta é essa, em que o indivíduo - de início "um joguete" - sai do jogo deixando a fulminante parceira desconcerta- 
da? É o jogo em que se mantém inviolada a retaguarda de segurança no plano da consciência, plano em que se afirma disfarçada mas integralmente o "eu mesmo", isto é, o lúcido jogador que aposta em si no embate das contradições.

Nessa retaguarda do humour, o alegado canhestrismo é de fato um valoroso coringa; na surpreendente dinâmica desta poesia, o leitor é alçado a uma posição de privilégio, como o parceiro de cartadas tão reveladoras. Trata-se, em suma, de uma operação poética para a qual os álibis e os truques líricos mais convencionais deixam de ter sentido em si mesmos, só importando, a cada poema, a iluminação de uma nova face contraditória. A garantia de atuação dessa forte consciência em todos os passos dispensa o leitor de qualquer complacência romântica com a tradição da poesia sentimental, dominante no lirismo luso-brasileiro. Intelectualmente provocado, o leitor é levado não a um ostensivo repertório de novidades ou revelaçōes, mas ao centro nervoso de um pensamento poético em que a consciência mais rigorosa se apresenta como uma outra e necessária face das paixōes e dos afetos mais intensos.

EXPLICAÇão: Este texto é, fundamentalmente, parte de um estudo maior sobre a poesia de Drummond que remeti ao CNPq em 1994, integrando o relatório referente à bolsa de Pesquisa concedida para meu projeto Consciência e lirismo em Drummond. Revi aqui e ali alguma formulação, além de acrescentar a referência ao livro Farewell, de 1996.

Alcides Villaça é professor de Literatura Brasileira da Universidade de São Paulo.

$50 \neg$ Alcides Villaça 